Dipublikasikan

Badan Pelaksana Kuliah Kerja Nyata

Universitas Lampung

Sekretariat Badan Pelaksana Kuliah Kerja Nyata, Universitas Lampung

Jt. Prof. Dr. Scemantri Brojonegoro No. 1, Bandar Lampung 35145.

\title{
PELATIHAN PEMBUATAN HANDSOAP DI SMP NEGERI 23 KRUI KECAMATAN LEMONG PESISIR BARAT SEBAGAI UPAYA PENANGGULANGAN COVID-19
}

\section{Agung Abadi Kiswandono ${ }^{1 *}$, R. Supriyanto ${ }^{1}$, Suci Wulan Dari', Dewi Nabila Sya'bania ${ }^{2}$, Dela Karlina ${ }^{2}$, Nurul Aini ${ }^{2}$, Alan Pratama ${ }^{2}$, Wahyu Triandy Yogo Sunyoto ${ }^{2}$}

\author{
${ }^{1}$ Jurusan Kimia FMIPA Universitas Lampung \\ ${ }^{2}$ Mahasiswa Kuliah Kerja Nyata, Universitas Lampung \\ Penulis Korespodensi : agungkiswandono@gmail.com
}

\begin{abstract}
Abstrak
Tujuan pelatihan adalah melatih kreativitas serta menanamkan wawasan sejak dini pada anak-anak sekolah tingkat Sekolah Menengah Pertama (SMP) Negeri mengenai pentingnya cuci tangan untuk pencegahan Covid-19 di Desa Lemong. Selain melihat implikasi sosialisasi ini untuk kesehatan masyarakat, kegiatan ini juga diharapkan dapat menciptakan usaha kecil untuk meningkatkan perekonomian masyarakat Desa Lemong melalui pengembangan pembuatan handsoap dengan bahan baku kimia yang mudah diperoleh di toko bahan-bahan kimia. Metode dalam pendampingan ini yaitu dengan menggunakan pendekatan dalam memberikan pemahaman pentingnya pengabdian masyarakat ini. Adapun langkah-langkah dalam pendampingan ini menggunakan tiga tahapan yaitu tahapan persiapan kegiatan, pelaksanaan kegiatan, dan penyelesaian kegiatan. Hasil yang diperoleh yaitu sebelum pendampingan ini dilaksanakan sebagian besar peserta didik di SMP Negeri 23 Lemong belum tahu bagaimana cara pembuatan handsoap dari bahan kimia. Setelah dilakukan sosialisasi pemahaman tentang cara pembuatan handsoap siswa SMP Negeri 23 Lemong terjadi peningkatan pengetahuan dan keterampilan dalam pembuatan handsoap dari bahan kimia. Menurut hasil survei yang dilakukan, pengetahuan siswa meningkat dan juga sudah paham betul cara mencegah dan menghindari Covid-19 dilihat dari presentase sejumlah $100 \%$.
\end{abstract}

Kata kunci: Covid-19; Desa Lemong, Handsoap

\begin{abstract}
The aim of this assistance is to train creativity and instill insights from an early age in junior high school children about the importance of washing hands for the prevention of Covid-19 in Lemong village. In addition to seeing the implications of this socialization for public health, this activity is expected to be able to create small businesses to improve the economy of the people of Lemong Village through the development of making handsoap with chemical raw materials that are easily obtained at chemical stores. The method in this mentoring is to use an approach in providing an understanding of the importance of community service. The steps in this assistance use three stages, namely the stages of activity preparation, implementation of activities, and completion of activities. The results obtained were that before this assistance was carried out most of the students at SMPN 23 Lemong did not know how to make handsoap from chemicals. After disseminating the understanding of how to make handsoap students of SMPN 23 Lemong, there was an increase in their knowledge and skills in making handsoaps from chemicals. According to the results of the survey conducted, students' knowledge increased and they also really understood how to prevent and avoid Covid-19 seen from a percentage of $100 \%$.
\end{abstract}

Key words: Covid-19; Lemong Village; Handsoap 


\section{Jurnal Pengabdian Kepada Masyarakat BUGUH}

Dipublikasikan

Badan Pelaksana Kuliah Kerja Nyata

Universitas Lampung

Sekretariat Badan Pelaksana Kuliah Kerja Nyata, Universitas Lampung.

J. Prof. Dr. Scemantri Brojonegoro No. 1, Bandar Lampung 35145.

\section{Pendahuluan}

Pandemi Covid-19 (corona virus disease 2019) mulai terjadi pada awal tahun 2020. Virus ini merupakan virus jenis baru yang dapat menular dari manusia ke manusia yang memiliki tingkat penyebaran yang sangat cepat. Wabah Covid-19 telah dinyatakan sebagai pendemi oleh WHO sejak 11 Maret 2020. Kasus positif Covid-19 di Indonesia pertama kali pada awal bulan Maret 2020. Presiden Joko Widodo memberikan informasi bahwa ada dua orang warga negara Indonesia yang terjangkit virus ini (Putri $d k k$., 2020). Penetapan itu didasarkan pada persebaran virus secara geografi yang telah mencapai 114 negara termasuk Indonesia. Penyebaran Covid-19 di Indonesia saat ini sudah semakin tinggi, dengan jumlah kasus terpapar Covid-19 semakin bertambah dari hari ke hari.

Sebagaimana telah menjadi pengetahuan umum (well-known), tangan adalah anggota badan yang kerap membawa dan menularkan bibit penyakit. Bahkan penyebaran Covid-19 ini juga salah satunya melalui tangan. Jika terkontaminasi dengan penderita, maka tangan yang telah terkontaminasi akan menyentuh hidung, mata dan mulut (Suprapto $d k k$. 2020). Pada kondisi new normal masyarakat wajib untuk menaati seluruh protokol yang telah dibuat oleh pemerintah sebagai bentuk komitmen dari masyarakat untuk menjadi masyarakat yang baik. Masyarakat harus dapat menyesuaikan diri dengan keadaan yang baru akibat adanya pandemi Covid-19. Tentunya adaptasi yang dilakukan oleh masyarakat akan sangat berhubungan dengan semua aspek yang ada di sekitar (Prameswari dan Satriawan, 2020). Rekomendasi standar untuk mencegah penyebaran infeksi adalah melalui cuci tangan secara teratur (Rudi, 2020), menerapkan etika batuk dan bersin, menghindari kontak secara langsung dengan ternak dan hewan liar serta menghindari kontak dekat dengan siapapun yang menunjukkan gejala penyakit pernapasan seperti batuk dan bersin (Yahya $d k k$., 2020). Mencuci tangan bermanfaat agar tangan menjadi bersih dan dapat membunuh mikroorganisme yang ada di tangan dan telah dibuktikan dari studi terdahulu dapat mencegah penyakit infeksi di masyarakat seperti diare, infeksi saluran pernafasan atas (ISPA) dan flu burung serta Covid-19 (Wahyuni dan Fatmawati, 2020). Penyakit infeksi biasanya terjangkit melalui kontak tangan ke tangan termasuk flu dan common cold. Salah satu cara untuk mengurangi risiko terinfeksi atau memutus mata rantai Covid-19 adalah mencuci tangan dengan air mengalir dan sabun (Kiswandono dan Nurhasanah, 2020). Molekul virus Corona dibalut oleh partikel protein dan lemak yang melindunginya dari air. Namun, ketika bersentuhan dengan sabun, perisai lemak tersebut akan terpecah dan virusnya akan ikut terbunuh kemudian air akan membilas sisa-sisa virus yang susah terpecah oleh sabun (Makhroji dan Nursamsu, 2020). Sabun cair pembersih tangan sendiri merupakan sabun untuk pembersih yang dibuat menggunakan proses saponifikasi menggunakan penambahan zat lain ataupun tanpa penambahan zat lain yang tidak menimbulkan iritasi kulit tangan.

Kegiatan ini memiliki sasaran khalayak khusus yaitu siswa SMP Negeri Krui. SMP Negeri 23 Krui merupakan Sekolah Menengah Pertama yang berawal dari SMP Negeri 2 Lemong yang terletak di Jalan Sahung Lemong Kecamatan Lemong Kabupaten Pesisir Barat Provinsi Lampung. Kegiatan ini bertujuan memberikan pengetahuan dalam menanamkan wawasan sejak dini pada siswa SMP Negeri 23 Krui mengenai pentingnya cuci tangan untuk mencegah Covid-19 serta memberikan keterampilan kepada mereka agar dapat membuat handsoap sendiri. Hal tersebut dilakukan mengingat bahwa anak yang sedang bersekolah tingkat menengah pertama (kisaran umur 12-14 tahun) merupakan salah satu bagian dari kelompok umur masyarakat yaitu tergolong remaja yang perlu sekali diedukasi agar dapat memberikan dampak baik tentang kebiasaan mencuci tangan kepada mereka, apalagi dalam masa pandemi Virus Covid-19 ini.

Upaya mewujudkan sekolah sehat adalah dengan melaksanakan perilaku hidup bersih, higienis dan sehat melalui kebiasaan mencuci tangan dengan sabun. Untuk anak-anak terutama usia sekolah dasar maupun remaja masih kurang sadar akan pentingnya cuci tangan menggunakan sabun. Mencuci tangan adalah suatu hal yang sederhana untuk menghilangkan kotoran dan meminimalisir kuman yang ada di tangan dengan mengguyur air dan dapat dilakukan dengan menambah bahan tertentu (Ardinata, 2016). 


\section{Jurnal Pengabdian Kepada Masyarakat BUGUH}

Dipublikasikan

Badan Pelaksana Kuliah Kerja Nyata

Universitas Lampung

Sekretariat Badan Pelaksana Kuliah Kerja Nyata, Universitas Lampung.

Ji. Prof. Dr. Soemantri Brojonegoro No. 1, Bandar Lampung 35145.

Maka dari itu, pada kegiatan pengabdian masyarakat ini dilakukan pendampingan pembuatan handsoap berbasis antiseptik yang diperoleh dari bahan kimia. Keterlibatan langsung siswa SMP dan didukung dengan kegiatan sosialisasi dalam meningkatkan kesadaran siswa SMP untuk melaksanakan perilaku hidup bersih dan sehat. Selain menjadi nilai tambah bagi sekolah dalam mengikuti kompetisi sekolah sehat tingkat nasional, kegiatan pengabdian masyarakat ini juga mendukung pelaksanaan protokol kesehatan di era kebiasaan baru saat pembelajaran yang dilaksanakan di sekolah. Mengingat hal tersebut dan perannya yang begitu penting dalam kehidupan masyarakat sehari-hari membuat sendiri handsoap dapat dipandang sebagai suatu kegiatan ekonomi yang cukup menguntungkan, baik untuk penghematan maupun untuk menambah penghasilan bila dikelola dengan baik dalam bentuk home industry.

Sabun sebagai salah satu kebutuhan utama untuk mendapatkan standar kebersihan yang baik dalam kehidupan sehari-hari termasuk dalam kebutuhan pokok, tetapi sabun tidak termasuk dalam kelompok kebutuhan primer. Apalagi dalam masa pandemi seperti ini sangat dibutuhkan handsoap untuk menjaga serta perlindungan ditubuh kita dari Virus Covid-19. Selain melihat implikasi sosialisasi ini untuk kesehatan masyarakat Desa Lemong, khususnya siswa SMP 23 Lemong, kegiatan ini diharapkan dapat menciptakan usaha kecil untuk meningkatkan perekonomian masyarakat Desa lemong melalui pengembangan pembuatan handsoap dengan bahan kimia yang mudah diperoleh sehingga lebih bermanfaat dan mempunyai nilai lebih.

\section{Bahan dan Metode}

Tahapan kegiatan pengabdian masyarakat ini dilakukan seperti apa yang pernah dilakukan oleh Kiswandono dkk (2020). Sosialisasi program ini dilakukan melalui metode pendekatan dalam rangka memberikan pemahaman tentang pentingnya pengabdian masyarakat perguruan tinggi, pendampingan untuk menanamkan wawasan sejak dini pada anak-anak sekolah tingkat SMP mengenai pentingnya cuci tangan untuk pencegahan Covid-19 serta mengubah mindset yang selama ini menjadi beban biaya tanpa hasil menjadi beban biaya yang memberikan kontribusi keuntungan.

Adapun metode pelaksaan pengabdian masyarakat ini sebagai berikut:

Persiapan Kegiatan Pelatihan Pembuatan Handsoap

Mengurus kerja sama dengan Wakil kesiswaan SMPN 23 Krui. Mempersiapkan tempat kegiatan; kegiatan dilakukan oleh peserta didik SMPN 23 Krui; mempersiapkan kelengkapan alat dan bahan (bahan-bahan pembuatan handsoap dapat dengan mudah ditemukan di toko kimia terdekat. Bahan dasar pembuatan sabun cair meliputi SLS, texapon dan garam serta bahan aditif seperti parfum, pengawet, pengental, foam booster, anti septik dan zat pewarna).

\section{Pelaksanaan Kegiatan}

Tahap ini meliputi koordinasi Tim Pengabdian Masyarakat Universitas Lampung bersama mahasiswa kuliah kerja nyata $(\mathrm{KKN})$ periode I tahun 2021 dengan kelompok mitra, koordinasi izin dan waktu kegiatan. Selain itu juga, persiapan bahan dan alat yang akan dibutuhkan dalam pelaksanaan program pengabdian. Selanjutnya adalah tahap pelaksanaan dengan agenda acara sosialiasi, edukasi tentang kehidupan new normal kepada kelompok mitra dan pendampingan pelatihan melalui demonstrasi secara langsung kepada kelompok mitra dengan metode focus group discussion (FGD) mengenai pembuatan handsoap.

Tahapan pembuatan handsoap adalah:
a. mempersiapkan air bersih sebanyak $14 \mathrm{~L}$.
b. melarutkan $1 \mathrm{~kg}$ texapon ke dalam $6 \mathrm{~L}$ air sambil diaduk terus hingga larut sempurna.
c. melarutkan $0,5 \mathrm{~kg}$ SLS ke dalam $4 \mathrm{~L}$ air sambil diaduk terus hingga larut sempurna.
d. menambahkan pewarna ke dalam 1 botol aqua lalu dikocok. 


\section{Jurnal Pengabdian Kepada Masyarakat BUGUH}

Dipublikasikan

Badan Pelaksana Kuliah Kerja Nyata

Universitas Lampung

Sekretariat Badan Pelaksana Kuliah Kerja Nyata, Universitas Lampung.

Jl. Prof. Dr. Scemantri Brojonegoro No. 1, Bandar Lampung 35145

e. mencampurkan bahan di atas yang telah dilarutkan lalu ditambahkan pewangi, foam booster dan antiseptik sambil diaduk hingga menyatu.

f. menambahkan $1 \mathrm{~kg} \mathrm{NaCl}$ yang telah dilarutkan dengan $3 \mathrm{~L}$ air ke dalam larutan pada langkah sebelumnya sambil diaduk terus hingga larut sempurna, mengaduk larutan tersebut hingga mengental sempurna, terakhir produk siap digunakan ataupun dipaketkan untuk dipakai.

\section{Penyelesaian Kegiatan dan Evaluasi Kegiatan}

Evaluasi kegiatan dilaksanakan pada tahap awal kegiatan dan tahap akhir kegiatan. Evaluasi dilakukan pada pelaksanaan program kegiatan meliputi materi penyuluhan dan pelatihan, teknologi yang diterapkan untuk produksi pembuatan handsoap serta managemen pengelolaan dan penjualan.

\section{Hasil dan Pembahasan}

Kegiatan pengabdian kepada masyarakat oleh mahasiswa KKN ini dilaksanakan pada 19 Februari 2021. Sosialisasi diawali dengan pemaparan materi berupa penjelasan kepada peserta didik SMPN 23 Krui (Gambar 1). Mengenalkan alat-alat dan bahan yang digunakan serta cara kerja dalam pembuatan handsoap. Kemudian dilanjutkan dengan melakukan praktek langsung pelatihan pembuatan handsoap, di mana siswa/i SMPN 23 Krui ikut serta berperan aktif dalam kegiatan ini.

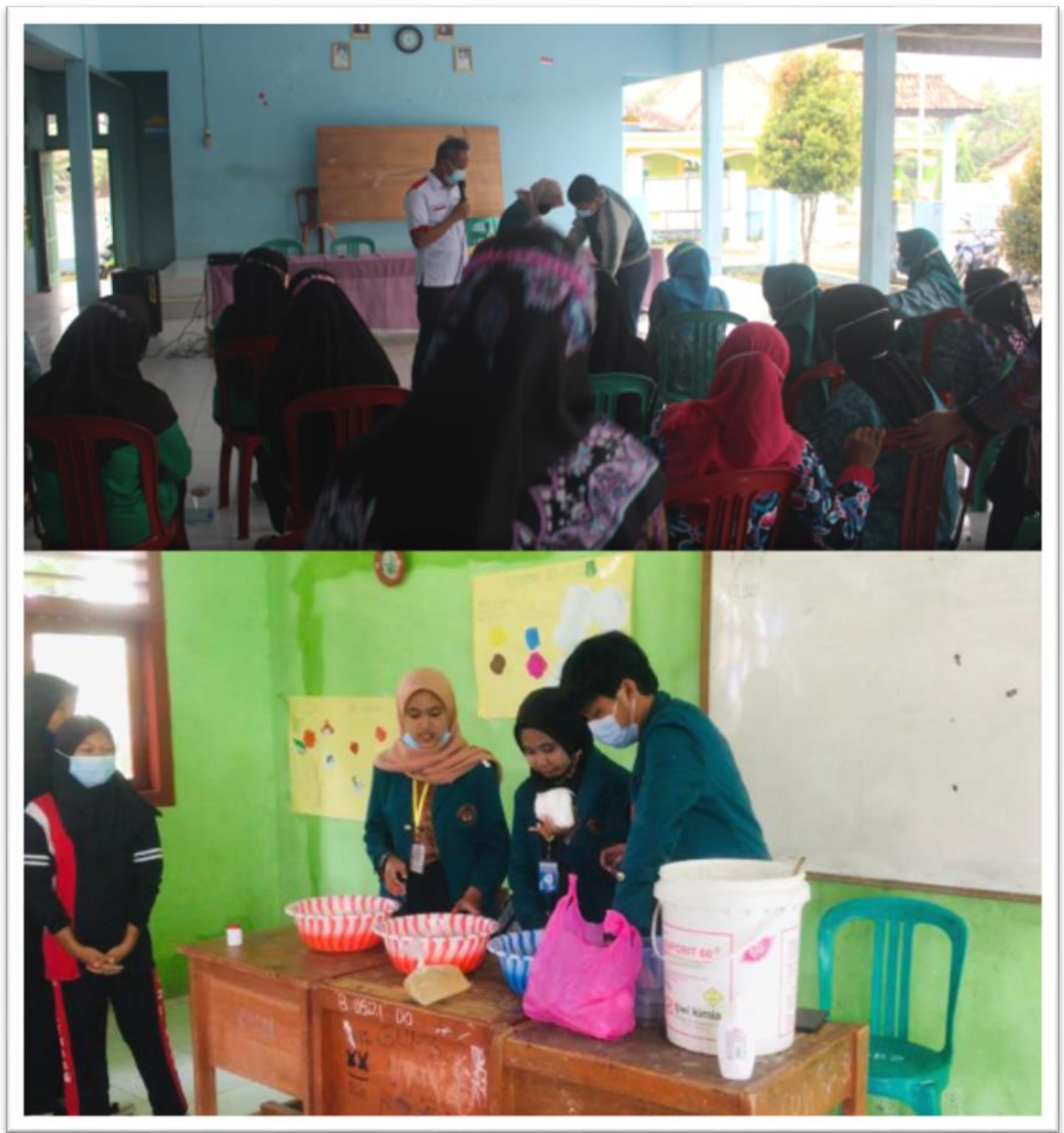

Gambar 1. Sosialisasi dan demonstrasi pembuatan handsoap 


\section{Jurnal Pengabdian Kepada Masyarakat BUGUH}

Dipublikasikan

Badan Pelaksana Kuliah Kerja Nyata

Universitas Lampung

Sekretariat Badan Pelaksana Kuliah Kerja Nyata, Universitas Lampung.

Ji. Prof. Dr. Soemantri Brojonegoro No. 1, Bandar Lampung 35145 .

Kegiatan pelatihan pembuatan handsoap dilaksanakan di SMPN 23 Krui, Kabupaten Pesisir Barat diikuti oleh peserta didik di sana yang sangat antusias (Gambar 2). Pencapaian tujuan kegiatan ini dapat dilihat dari antusiasnya siswa SMPN 23 Krui dalam mengikuti kegiatan dan menerapkannya langsung setelah mengikuti kegiatan tersebut. Salah satu upaya untuk menjaga kesehatan adalah dengan mencuci tangan. Hal ini dikarenakan dengan mencuci tangan dapat mencegah penyakit infeksi (Panca, 2015). Mencuci tangan dapat menurunkan jumlah kuman di tangan sampai dengan 58\% (Panca, 2015). Pembuatan handsoap selain sebagai peluang usaha tentu berfungsi melindungi diri dari berbagai macam infeksi dan penyakit berbahaya serta mencegah penyebaran bakteri ataupun virus ke orang lain melalui tangan.

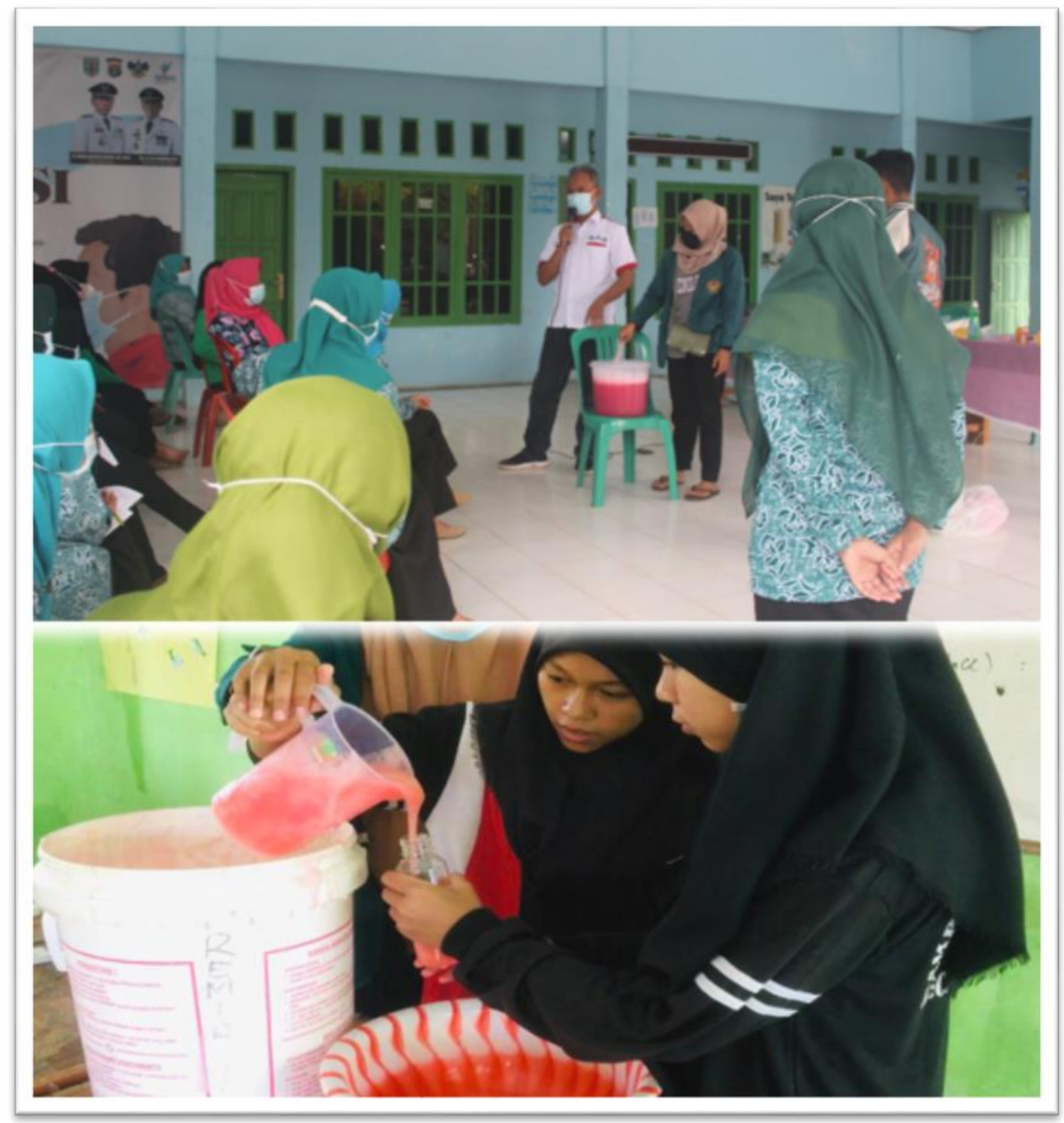

Gambar 2. Praktek pembuatan handsoap oleh Siswa SMPN 23 Krui

Hasil dari pelatihan pembuatan handsoap ini berupa sabun cuci tangan cair berwarna merah muda, berbau harum, tidak membuat kasar tangan apabila sabun cuci tangan cair ini dipakai (Gambar 3). Selain digunakan untuk keperluan sehari-hari, sabun cuci tangan cair ini juga dapat dipasarkan sehingga dapat menambah pendapatan dan yang terpenting, siswa SMPN 23 Krui mendapatkan ilmu serta wawasan 


\section{Jurnal Pengabdian Kepada Masyarakat BUGUH}

Dipublikasikan

Badan Pelaksana Kuliah Kerja Nyata

Universitas Lampung

Sekretariat Badan Pelaksana Kuliah Kerja Nyata, Universitas Lampung.

Jt. Prof. Dr. Scemantri Brojonegoro No. 1, Bandar Lampung 35145.

mengenai pembuatan handsoap. Kegiatan ini diawali dengan melakukan survei kelapangan, hasilnya menunjukkan bahwa banyak peserta didik yang belum mengetahui cara pembuatan handsoap.

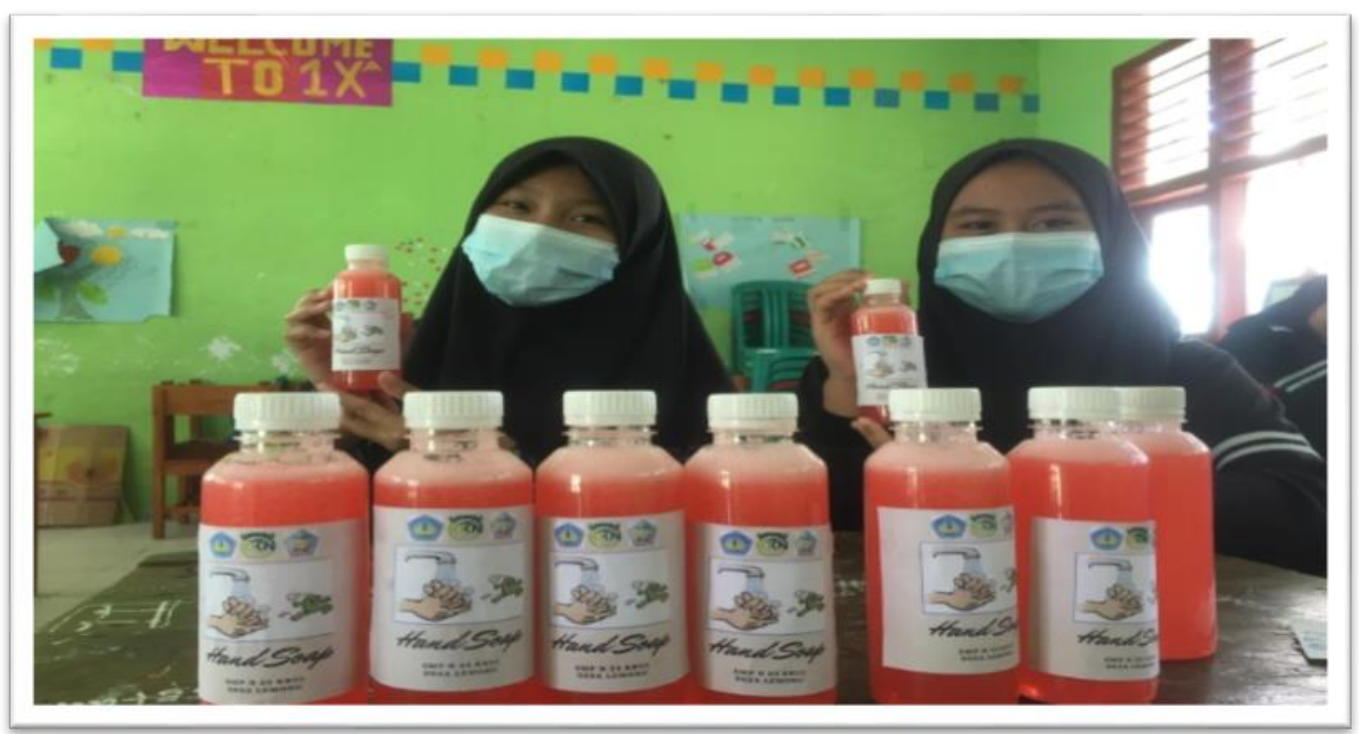

Gambar 3. Produk handsoap telah selesai dibuat dan dikemas dalam botol

Setelah dilakukannya sosialisasi kepada peserta didik SMPN 23 Krui, mereka mampu memahami dan menjelaskan bagaimana proses pembuatan handsoap. Dari kegiatan tersebut, dihasilkan produk handsoap (Gambar 3) dan dibagikan kepada para guru, peserta didik SMPN 23 Krui dan masyarakat Desa Lemong. Dampak kegiatan ini seperti terlihat pada Tabel 1. Kegiatan ini sangat membantu memutus mata rantai Covid-19 dan dapat mencegah penyebaran virus melalui cuci tangan menggunakan handsoap.

Tabel 1. Dampak perubahan peserta pelatihan

\begin{tabular}{|c|c|}
\hline $\begin{array}{c}\text { Sebelum } \\
\end{array}$ & $\begin{array}{l}\text { Sesudah } \\
\end{array}$ \\
\hline $\begin{array}{l}\text { 1. Siswa SMPN } 23 \text { Krui belum paham } \\
\text { betul bagaimana proses pembuatan } \\
\text { handsoap. }\end{array}$ & $\begin{array}{l}\text { 1. Siswa SMPN } 23 \text { Krui sudah bisa } \\
\text { membuat handsoap } \\
\text { 2. Siswa SMPN } 23 \text { Krui sudah paham }\end{array}$ \\
\hline $\begin{array}{l}\text { 2. Siswa SMPN } 23 \text { Krui belum paham } \\
\text { tentang penerapan dan pemahaman } \\
\text { protokol kesehatan. } \\
\text { 3. Siswa SMPN } 23 \text { Krui masih banyak } \\
\text { yang belum menerapkan cuci tangan } \\
\text { dan memakai masker. }\end{array}$ & $\begin{array}{l}\text { 3. Masyarakat Siswa SMPN } 23 \text { Krui } \\
\text { kebanyakan sudah menerapkan cuci } \\
\text { tangan dan memakai masker. }\end{array}$ \\
\hline
\end{tabular}

Kemampuan siswa SMPN 23 Krui sesudah adanya transfer metode pembuatan handsoap, diharapkan:

1. Mampu membuat sabun tangan cair yang disertai dengan pemahaman dasar akan sabun;

2. Mampu mengatur (me-manage) efisiensi maupun efektifitas penggunaan sabun cair agar tidak boros dalam pemakaiannya;

3. Mampu mengoordinasikan sistem atau cara pembuatan sabun di lingkungan tempat tinggal;

4. Mampu menjadikan sabun sebagai terobosan untuk memperoleh tambahan uang jajan;

5. Mampu menghitung keuntungan yang dapat diperoleh dengan memanfaatkan peluang wirausaha.

Dengan demikian, pengetahuan dan keterampilan masyarakat Desa Lemong, khususnya siswa SMPN 23 Krui meningkat dalam upaya menjaga kebersihan tangan untuk mencegah penyebaran Virus Covid-19. 


\section{Jurnal Pengabdian Kepada Masyarakat}

\section{BUGUH}

Dipublikasikan

Badan Pelaksana Kuliah Kerja Nyata

Universitas Lampung

Sekretariat Badan Pelaksana Kuliah Kerja Nyata, Universitas Lampung.

Jt. Prof. Dr. Soemantri Brojonegoro No. 1, Bandar Lampung 35145.

\section{Kesimpulan}

Kesimpulan setelah melakukan pengabdian masyarakat ini dapat meningkatkan pengetahuan dan keterampilan sebagian besar peserta didik di SMPN 23 Krui dalam pembuatan handsoap yang dapat digunakan pribadi maupun dikomersilkan. Selain itu juga membangkitkan minat para generasi muda untuk berwirausaha secara mandiri.

\section{Daftar Pustaka}

Ardinata, M.F. 2016. Perbandingan Efektivitas Metode Mencuci Tangan Menggunakan Sabun dengan Menggunakan Handrub dalam Membunuh Bakteri pada Perawat RS Pendidikan Universitas Sumatera Utara (skripsi). Medan: Universitas Sumatera Utara.

Kiswandono, A.A., \& Nurhasanah. (2020). Covid19 Disrupsi \& Tatanan Sosial Budaya, Ekonomi, Politik dan Multi: Catatan Sebuah Pengabdian "Hidup Sehat Tanpa Covid-19: Produk Pembasmi Covid-19 di Desa Fajar Baru dan Triharjo, Kabupaten Lampung Selatan". Pusaka Media. Bandar Lampung.

Kiswandono, A.A., Nurhasanah, dan Akmal, J. (2020). Pelatihan dan Pendampingan home industri kelompok PKK Desa Fajar Baru: Pembuatan Detergen Cair. Jurnal Sakai Sambayan. Volume 4, No. 1. 72-77

Lette, A. (2020). Sosialisasi Pencegahan Covid-19 Melalui Brosur di RT 20/Rw 07 Kelurahan Fatufeto Kota Kupang. Jurnal Pengabdian Kepada Masyarakat, 1(4), 236-242.

Makhroji, H. \& Nursamsu. (2020). Pelatihan Pembuatan Sabun Cuci Tangan Cair untuk Pencegahan Penularan Covid di Desa Matang Teupah. Jurnal Pengabdian Kepada Masyarakat,4, 30-37

Panca, E. (2015). Efektivitas Handshop dan Hand Sanitizer terhadap Penurunan Angka Kuman pada Telapak Tangan di Badan Perpustakaan Provinsi Kalimantan Timur (skripsi). Kalimantan Timur: STIK Muhammadiyah.

Prameswari, A.M. \& Satriawan, D. (2020). Sosialisasi Pencehan Covid-19 Melalui Prilaku Hidup Bersih di Kampung Juku Batu Kecamatan Banjit Kabupaten Way Kanan. Jurnal Pengabdian kepada Masyarakat, 1(2), 35-40.

Putri, V.S., Kartini, \& Furqani, A. (2020). Pencegahan Penyebaran Covid-19. Open Journal System, 1, 25-32.

Rudi, A. (2020). Sosialisasi Cuci Tangan Pakai Sabun Dengan Air Mengalir Sebagai Upaya Pencegahan Covid-19 Pada Siswi-Siswi SD Muhammadiyah Sintang, Kalimantan Barat. Jurnal Pengabdian Kepada Masyarakat (JURPIKAT), 1(3), 241-248.

Suprapto, R., Hayati, M., Nurbaity, S., Anggraeni, F., Haritsatama, S., Sadida, T.S., Firoh, A. (2020). Pembiasaan Cuci Tangan yang Baik dan Benar pada Siswa Taman Kanak-Kanak (TK) di Semarang. Jurnal Surya Masyarakat, 2(2), 139-145.

Wahyuni, W. \& Fatmawati, S. (2020). Penigkatan Pengetahuan PBHS dan Penerapan Cuci Tangan dalam Upaya Pencegahan Covid-19 Pada Santri di Lingkungan Pondok Pesantren. Jurnal Pengabdian Kepada Masyarakat, 4, 197-204

Yahya, M., Fathahillah, \& Megavitry, R. (2020). Penerapan Alat Cuci Tangan Guna Pencegahan Penyebaran Virus Covid-19 di Desa Lagaruda. Jurnal Desikasi. 22. 143-147. 